\title{
Effect of Hydrocarbon Yeast as Dietary Protein Source on Reproducibility of Breeding Hens
}

\author{
V. Combined Analyses of Multi-generation Feeding Experiment
}

\author{
Minoru Yoshida ${ }^{1)}$, Masao $\mathrm{TADA}^{2)}$, Hiroyuki Bansho ${ }^{3)}$, Masahiro Matsushima ${ }^{4)}$ \\ Kenji $\mathrm{KoBA}^{5)}$, Masao IINo $^{6 /}$ and Isao UMEDA ${ }^{71}$ \\ 1) National Institute of Animal Industry, Chiba-shi \\ 2) Okayama Prefectural Poultry Experiment Station, Mitsu-gun, Mitsu-machi \\ 3) Hiroshima Prefectural Livestock Experiment Station, Miyoshi Branch, Miyoshi-shi \\ 4) Tottori Prefectural Swine and Poultry Experiment Station, Yonago-shi \\ 5) Kumamoto Prefectural Poultry Experiment Station, Tamana-shi \\ 6) Saitama Prefectural Poultry Experiment Station, Iruma-gun, Hidaka-cho \\ 7) Gifu Prefectural Poultry Breeding Station, Seki-shi
}

Yeast grown on $n$-paraffin, which is called hydrocarbon yeast or just yeast in this paper, is one of the most hopeful protein source for domestic animals and poultry in Japan, where more than half of the protein source for feed use is imported. Production of animal foods, meat and eggs, by feeding yeast to poultry necessarily means that human beings take $n$ paraffin, a product of petrolium refining, though very indirectly through yeast and then through poultry. Although yeast grown on sulfite waste liquor has been used as feed ingredient for long time, this is the first trial to produce animal protein food on yeast grown on $n$-paraffin, and therefore, presence of any toxicity or adverse eflect in yeast should be examined carefully before using the yeast as protein feed. Certainly, it is our duty to ascertain the safety of food produced by feeding hydrocabon yeast to domestic animals and poultry.

In 1969, multi-generation feeding experiment was designed to study the eflect of feeding yeast to breeding hens and cocks for six generations as a collaborative project of National Institutes of Animal Industry and of Animal Health and six Prefectural Poultry Experiment or Breeding Stations. In these collaborative project, chemical analyses and determination of nutritive value of four kinds of yeast used in the experiment and nutritional and toxicological study of lipid extracted from the yeast had been carried out in National Institute of Animal Industry ${ }^{1,2)}$. In six prefectural experiment stations, long-term multi-generation feeding experiment with hatchability tests had been carried out ${ }^{3 \sim 6)}$. Post-mortem and histopathological examinations had been carried out in each of the stations, then the preparations for microscope was sent to National Institute of Animal Health for re-examination. At the end of the long-term feeding experiment, the hens of the third generation were sacrificed and the samples of the meat and eggs were taken for chemical analyses and for sensory test in National Institute of Animal Industry.

Performance of the hens from the first through fifth generation were summarised and analysed statistically at the end of the whole project, though most of the observations in this collaborative project had already been published in this Journal ${ }^{1 \sim 8)}$. In this paper, are

Received December 14, 1974. 
presented the data of the summarized analyses on performance of the hens with the data on chemical analyses of the meat and eggs of the hens of the third generation.

\section{Experimental}

Experimental design: The experimental design is illustrated briefly in Fig. 1. As reported already $^{3 \sim 5}$, in each of the six stations at least 200 female and a number of male one-day-old White Leghorn chicks were divided into two, one receiving a diet containing $15 \%$ of yeast and the other receiving a control diet. In laying house, each of the two groups were further sub-divided into five lots of 20 females each. The hens were mated or artificially inseminated with the cocks raised on the same diet as the hens took. At 36, 44 and 52 weeks of age, eggs of the hens on each of the diets were set in an incubator for hatchability test. Ten hens each on each of the diets in each of the stations were sacrificed for histopathological examination, taking samples from 25 organs per bird.

The offspring of the second hatchability test were raised as the second generation in exactly the same manner as the first generation. The offspring of the second, third and fourth generation were raised as their parents, except that two lots of 20 hens each for the fourth and fifth generation were raised instead of five lots each for the first, second and third generation. The offspring of the fifth generation were raised on the conventional teed in each of the stations for two weeks.

Feeding experiments of the hens of the first through fifth generation were terminated at 52,44 or 36 weeks of age as shown in Fig. 1, with one to three hatchability tests.

Sixty hens, i.e. three lots of 20 hens each, of the third generation on each of the two diets in each of six stations were reared further for longer than two years to get the samples for histopathological examination, because it was pointed out that the hens of one year of age in the first histopathological examination was too young. Before terminating this longterm feeding experiment with the hens of the third generation, one hatchability test was carried out and sample of the meat and eggs for chemical analyses and for sensory test were obtained.

Yeast and diet: Four kinds of yeast, Yeast A, B, C and D, were tested. Yeast A was

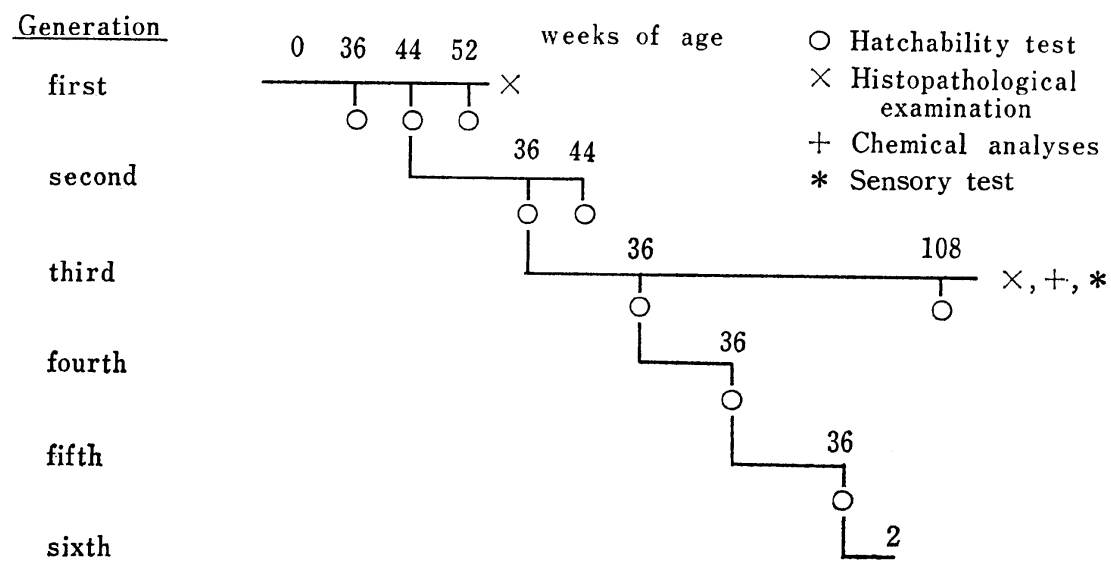

Fig. 1. Scheme of multi-generation feeding experiment. 
Candida produced by Kyowa Hakko Kogyo Co. Ltd.. Yeast B was Candida produced by Kanegafuchi Chemical Industry Co., Ltd.. Yeast C was Candida produced by Asahi Chemical Industry Co., Ltd.. Yeast D was Pichia produced by Dainipponink \& Chemicals, Inc. Chemical composition of these four kinds of yeast was determined and published at the beginning of this collaborative project ${ }^{1,3}$. Crude protein content in Yeast $\mathrm{D}$, which was the lowest among four ${ }^{1,3)}$, was improved during the long-term experimental period and a sample of Yeast D produced at the end of the experiment contained $62.6 \%$ of crude protein on dry basis.

The composition of the control and yeast diets was as reported previously ${ }^{3,4)}$, which was mainly composed of yellow corn, soybean meal, fish meal, rice bran, wheat bran, alfalfa meal, and supplements. The yeast diet contained 15\% of one of four kinds of yeast and $85 \%$ of a basal diet. The control and basal diets were prepared in a commercial feed manufacturer under the instruction of National Institute of Animal Industry and distributed to each of the stations. In each station, 15 parts of yeast was mixed with 85 parts of the basal diet to make up the yeast diet. By this way of preparation, levels of nutrients in the control and yeast diets could not be adjusted exactly, because of slight difference in nutrients content of four kinds of yeast.

Statistical analyses: For each of the measured items summarized in Table 1, averages of each of the generation in each of the stations were analyzed statistically as mentioned previously ${ }^{4}$. Sum of squares of error 1 estimated for each generation ${ }^{3 \sim 5}$, was pooled and divided by harmonic mean of repeat in each station to estimate error variance ${ }^{9}$. Since no interaction between diet and each of two other factors was significant statistically, only the main effect of diet was presented in Table 1.

In the statistical analyses, viabilities during the growing and laying stages and fertility in hatchability test were transformed into angle, i.e. arcsin $\sqrt{\text { percentage. }}$

Chemical analyses: One sample each of four kinds of yeast and of the control diet was taken from four stations, i.e. Okayama, Tottori, Kumamoto and Saitama, and one sample each of the meat and eggs on either the control or yeast diet in each of six stations were taken for chemical analyses.

Nucleic acid was determined spectrophotometrically at $260 \mathrm{~m} \mu$ after separating the sample into three fractions, i.e. cold acid-soluble fraction, ribonucleic acids and deoxyribonucleic acids $^{10,11}$. Mercury was determined spectrophotometrically at $253.7 \mathrm{~m} \mu$ using Shimadzu 201 Mercury Meter after burning the sample in oxygen, absorbing in sulphuric acid with potassium permanganate and releasing mercury vapor ${ }^{12)}$. Lead and cadmium were determined by atomic absorption after ashing the sample with nitric and sulphuric acids ${ }^{13}$. Arsenic was determined colorimetrically with silver diethyl dithiocarbamate reagent ${ }^{13)}$.

Polycyclic aromatic compounds were determined fluorometrically after extraction by isooctane, clean-up by florisil column, solvent-solvent separation with dimethyl sulphoxide and separation by thin layer chromatogram ${ }^{14,15}$.

Determination of heavy metal and polycyclic aromatic compounds was carried out in Japan Food Research Laboratories. 


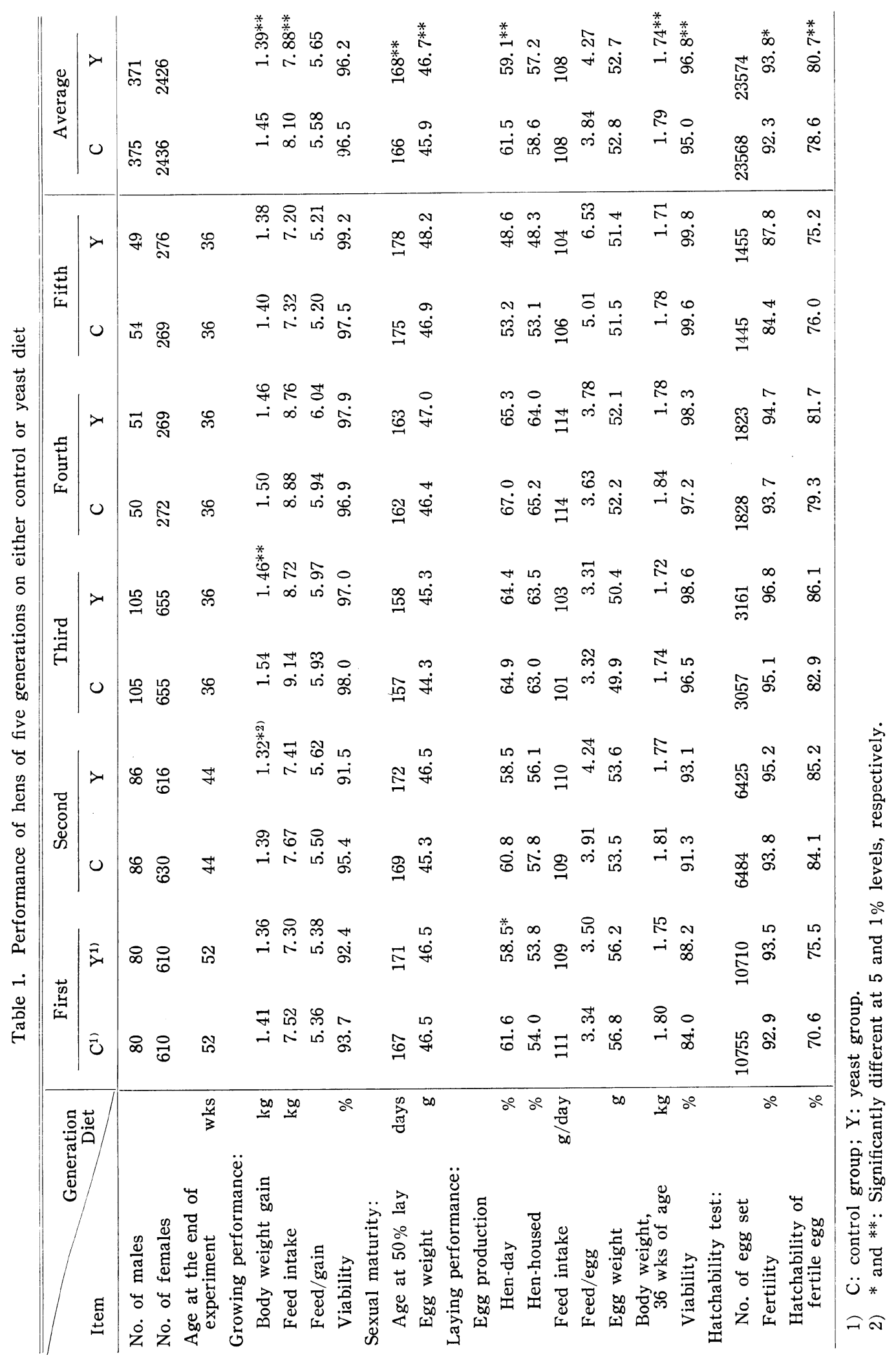




\section{Results}

Average performance of the hens of five generations on each of the diets and grand mean on each of the diets are presented in Table 1. For each generation, consistent trend of slightly slower growth rate, less feed intake, delayed maturity with heavier initial egg weight of the hens on the yeast diet than those on the control diet was observed and the trend was confirmed statistically in combined analyses of five generations. On the other hand, feed conversion (feed/gain) and viability during the growing stage was almost identical between the hens on the two diets.

Performance of the hens during the laying stage was almost identical between the hens on the two diets, except significantly lower hen-day egg production, lighter body weight at 36 weeks of age and higher viability of the hens on the yeast diet than those on the control diet. Since egg production was recorded during 20 through 36 52 weeks of age, delayed sexual maturity on the yeast diet had rather large inffuence on average hen-day egg production, while superior viability on the yeast diet during the laying stage had favorable influence on hen-housed egg production.

Both fertility and hatchability of fertile egg was better on the yeast diet than those on the control diet. The diflerence was small, being 1.5 and $2.1 \%$ in average, respectively, but was significant statistically.

Contents of nucleic acids, heavy metals and polycyclic aromatic compounds in the samples of yeast, the control diet, and the meat and eggs on the control and yeast diets are presented in Tables 2, 3 and 4, respectively. In these tables, average and standard deviation of the content are presented when the substances were determined in all of the samples tested. Average content and number of samples undetectable are presented in these tables when the substances were not detectable in some of the samples tested. Four samples of the control diet were obtained from four stations, to where the diet of the same lot was distributed from the feed manufacturer. Therefore, variation of the content in four samples of the control diet was corresponded to sampling error.

Table 2. Content of nucleic acids

\begin{tabular}{|c|c|c|c|c|c|c|}
\hline Sample & $\begin{array}{l}\text { No. of } \\
\text { sample }\end{array}$ & Moisture & $\begin{array}{l}\text { Cold acid } \\
\text { soluble } \\
\text { as RNA }\end{array}$ & $\begin{array}{l}\text { Ribonucleic } \\
\text { acids }\end{array}$ & $\begin{array}{l}\text { Deoxyribo- } \\
\text { nucleic } \\
\text { acids }\end{array}$ & Total \\
\hline Control diet & 4 & $9.62 \%$ & $0.31 \pm 0.02 \%$ & $0.78 \pm 0.03 \%$ & $0.15 \pm 0.01 \%$ & $1.24 \pm 0.05 \%$ \\
\hline Yeast A & 1 & 4.68 & 3.20 & 5.50 & 0.33 & 9.03 \\
\hline "I B & 1 & 5.87 & 3.20 & 6.07 & 0.59 & 9.86 \\
\hline$"$ C & 1 & 6.72 & 2.20 & 5.40 & 0.49 & 8.09 \\
\hline$\prime \prime \quad \mathrm{D}$ & 1 & 6.24 & 3.20 & 5.27 & 0.37 & 8.84 \\
\hline Meat: Control & 6 & 70.05 & $0.29 \pm 0.04$ & $0.14 \pm 0.01$ & $0.05 \pm 0.01$ & $0.48 \pm 0.04$ \\
\hline Yeast $^{2)}$ & 6 & 74.10 & $0.30 \pm 0.03$ & $0.15 \pm 0.02$ & $0.06 \pm 0.02$ & $0.51 \pm 0.02$ \\
\hline Egg: Control & 6 & 74.94 & $0.06 \pm 0.01$ & $0.05 \pm 0.01$ & $0.02 \pm 0.003$ & $0.12 \pm 0.01$ \\
\hline Yeast $^{2)}$ & 6 & 74.38 & $0.05 \pm 0.01$ & $0.05 \pm 0.01$ & $0.02 \pm 0.002$ & $0.12 \pm 0.01$ \\
\hline
\end{tabular}

1) Mean \pm standard deviation.

2) Average of 6 samples is presented since no statistically significant difference was observed among the samples on different kinds of yeast. 
Table 3. Content of mercury, lead, cadmium and arsenious oxide

\begin{tabular}{|c|c|c|c|c|c|}
\hline Sample & No. of sample & $\mathrm{Hg}$ & $\mathrm{Pb}$ & $\mathrm{Cd}$ & $\mathrm{As}_{2} \mathrm{O}_{3}$ \\
\hline Control diet & 4 & $0.02 \pm 0.01^{11}$ & $\begin{array}{r}\text { ppm } \\
0.35(1 / 4)^{2}\end{array}$ & $0.08 \pm 0.03$ & $\begin{array}{c}\text { ppm } \\
0.27(1 / 4)\end{array}$ \\
\hline Yeast A & 1 & 0.01 & 0.30 & 0.04 & $-3)$ \\
\hline "I B & 1 & 0.01 & 0.32 & - & - \\
\hline$\prime \prime \quad C$ & 1 & 0.03 & 0.13 & 0.10 & 0.3 \\
\hline$\prime \quad \mathrm{D}$ & 1 & 0.01 & - & - & - \\
\hline Meat: Control & 6 & $0.01(1 / 6)$ & $0.10 \pm 0.005$ & $0.01(2 / 6)$ & $0.12(2 / 6)$ \\
\hline Yeast & 6 & $0.01(1 / 6)$ & $0.10(1 / 6)$ & $0.01(5 / 6)$ & $0.10(5 / 6)$ \\
\hline Egg: Control & 6 & $0.015 \pm 0.005$ & $0.16(4 / 6)$ & $-(6 / 6)$ & $-(6 / 6)$ \\
\hline Yeast & 6 & $0.013 \pm 0.005$ & $0.11(2 / 6)$ & $-(6 / 6)$ & $-(6 / 6)$ \\
\hline Sensitivity & & 0.01 & 0.05 & 0.01 & 0.1 \\
\hline
\end{tabular}

1) Mean \pm standard deviation.

2) Mean of detectable data. Figures in parenthesis are No. of samples undetected/total No. of samples.

3) Undetectable.

Table 4. Content of polycyclic aromatics

\begin{tabular}{|c|c|c|c|c|c|}
\hline Sample & No. of sample & 3,4-Benzpyrene & $\begin{array}{l}\text { 20-Methyl- } \\
\text { cholanthrene }\end{array}$ & $\begin{array}{l}\text { 1,2,5,6-Dibenz- } \\
\text { anthracene }\end{array}$ & Benzpyrene \\
\hline Control diet & 4 & $\begin{array}{r}\mathrm{ppb} \\
0.09(1 / 4)^{1)}\end{array}$ & $-2)$ & - & - \\
\hline Yeast A & 1 & + & - & + & - \\
\hline "l $\mathrm{B}$ & 1 & 0.09 & - & + & - \\
\hline$\prime \prime \quad \mathrm{C}$ & 1 & 0.18 & - & + & - \\
\hline$\prime \prime \quad \mathrm{D}$ & 1 & + & - & + & - \\
\hline Meat: Control & 6 & - & - & - & - \\
\hline Yeast & 6 & - & - & - & - \\
\hline Egg: Control & 6 & - & - & - & - \\
\hline Yeast & 6 & - & - & - & - \\
\hline+ value & & $0.01<\mathrm{x}<0.05$ & $1<\mathrm{x}<10^{\mathrm{ppb}}$ & $\begin{array}{c}\text { ppb } \\
1<\mathrm{x}<10^{-1}\end{array}$ & $\begin{array}{c}\text { pp } \\
1<x<10\end{array}$ \\
\hline
\end{tabular}

1) Content in one of 4 samples. Figures in parenthesis means that 3,4-benzpyrene was not detected in one sample out of 4 . Content in the rest was + value.

2) Undetected from all of the samples.

Content of total nucleic acids in the yeast was between $8.1 \sim 9.9 \%$, but it had little effect on content of nucleic acids in the meat and eggs on the yeast diet.

Heavy metals and polycyclic aromatic compounds in the yeast were almost identical to or rather smaller than those in the control diet, and had little influence on their content in the meat and eggs on the yeast diet. Difference in the content of nucleic acids, heavy metals and polycyclic aromatic compounds in the meat and eggs on either the control or yeast diet was not significant statistically.

\section{Discussion}

Statistical analyses of variance of the data of the hens of five generations revealed clearly 
the smaller feed intake on the yeast diet during the growing stage, resulting in the lower body weight gain and delayed sexual maturity with heavier first egg. It should be pointed out that the dietary levels of nutrients in the control and yeast diets was not exactly identical, as mentioned above. Furthermore, without exact adjustment in dietary phosphorus level, high phosphorus content in the yeast resulted in unbalance of calcium and phosphorus levels in the yeast diet. Since it was confirmed that growth rate and feed intake of the chicks on the yeast was almost exactly identical to those on the control diet, if dietary energy, protein, calcium and phosphorus levels be adjusted exactly with supplementation of vitamin $\mathrm{B}_{12^{16,17}}$, it was certain that smaller feed intake and slower growth rate on the yeast diet shown in Table 1 was not due to the ill effect of yeast itself, but due to the unbalanced level of nutrients, especially of phosphorus, in the yeast diet.

It is well known as reviewed by one of the authors ${ }^{18)}$ that the restricted feed supply during the growing stage resulted in smaller body size both at sexual maturity and at adult stage with delayed sexual maturity but larger first egg. Delayed sexual maturity resulted naturally in lower egg production in the earlier laying period but not in the whole laying periods. Therefore, apparent adverse eflect of the yeast diet in the growing stage and on sexual maturity could be well explained by the restriction of feed intake during the growing stage due to the unbalance of nutrients, especially of phosphorus, in the yeast diet. Supplementation of large amount of calcium cabonate in the layer diets for egg shell production certainly made the hens free from the ill effect of high dietary phosphorus level in the yeast diet.

The data in the long-term feeding experiment of the third generation reported previously $\left.{ }^{6}\right)$ revealed that lower egg production on the yeast diet was only observed in the first laying period, i. e. from 20 to 28 weeks of age, and that egg production on the yeast diet was superior slightly to that on the control diet after the second laying period and the difference in egg production between the hens on two diets was getting larger after the seventh period, i. e. after 76 weeks of age. Egg production on the yeast diet during the whole experimental period of 88 weeks was significantly higher than that on the control diet. The findings supports the discussion mentioned above.

Besides the apparent adverse effect of the yeast diet in the growing stage, which could be avoided simply by careful adjustment of dietary levels of nutrients, the data shown in Table 1 in this paper and in Fig. 1 in the previous paper $\left.{ }^{6}\right)$ indicated that the yeast tested had some favorable effect to keep high viability with high egg production. The effect was especially apparent when the hens suffered from Marek's disease as reported previously ${ }^{3.4)}$. Although the reason was unknown, higher fertility and higher hatchability of fertile egg also suggested the effect of yeast, activating the reproductive ability of both males and females.

Since the yeast grown on $n$-paraffin is a novel protein source produced from carbon source of petrolium-origin, many anxiety had been expressed on safety of the meat and eggs produced on the yeast. One type of possible toxic or unfavorable substances was those from the raw materials of yeast fermentation. Polycyclic aromatic compounds, which are suspected to be carcinogenic, and heavy metals are of this type. As shown in Tables 3 and 4 , the yeast certainly contained some of these, but the amount in the yeast was as in the control diet, and yeast feeding had little influence on the content of these substances in the meat and 
eggs.

Another type of substances of possible toxicity was those produced by the yeast, such as mycotoxin, nucleic acids and odd-number fatty acids. No growth retardation was observed by the yeast feeding if dietary nutrients levels were carefully adjusted ${ }^{16,17)}$, and little difference was observed between the hens on either the control or yeast diet in post-mortem and histopathological examinations, so that no evidence was obtained suggesting the presence of toxin in the yeast. Since energy in lipid extracted from the yeast ${ }^{2)}$ and in odd-number fatty acids $^{19)}$ was utilized by chicks almost completely, and no adverse effect was observed by long-term and multi-generation feeding of the yeast, no evidence was also obtained suggesting the toxicity of odd-number fatty acids. Content of total nucleic acids in the yeast, which are suspected to cause human gout, was about $9 \%$, but had no influence on the nucleic acid content of the meat and eggs as shown in Table 2. Actually, it is reasonable and practical way for removal of nucleic acids from yeast protein to feed the yeast to poultry, getting the meat and eggs.

The third type was unknown toxic substances which might be contained in the yeast. The performance of the chicks and hens reported in this and previous papers ${ }^{1 \sim 8,16,17)}$, as well as many others published in this and foreign countries, suggested little possibility of the existence of such an unknown toxic substance or substances in the yeast. In post-mortem and histopathological examinations ${ }^{8,20,21)}$, no abnormality due to the yeast feeding was observed. Significantly higher hatchability on the yeast diet than that on the control diet as shown in Table 1 should be pointed out again. Since almost all of deformed chicks can not hatch, breaking their egg shell, hatchability gives important information on teratogenicity.

\section{Conclusion}

Four kinds of yeast grown on $n$-paraffin by four domestic manufacturers contained $57 \sim$ $65 \%$ of crude protein on dry basis with almost similar amino acid composition ${ }^{21)}$ and excellent digestibility of $83 \sim 86 \%$. Metabolizable energy of the yeast was $2.85 \sim 3.38 \mathrm{kcal} / \mathrm{g}$ on dry basis. The yeast was an excellent source of protein, energy and phosphorus for poultry, except sulphur amino acids and vitamin $\mathrm{B}_{12}$, of which content in the yeast was low for poultry feed, resembling the nutritive nature of soybean meal.

No data were obtained suggesting that the yeast feeding was unfavorable to produce the meat and eggs of good quality ${ }^{7,8)}$. No evidence was obtained indicating that the yeast contained a large quantity of heavy metals and polycyclic aromatic compounds to be injurious to human health through the meat and eggs produced by the yeast feeding.

Instead, it was suggested that the yeast contained some vital factor or factors which kept hens on the yeast healthy and productive, especially when the hens were under suboptimum condition, such as suffered from disease ${ }^{3,1)}$ or getting older ${ }^{6}$. Furthermore, the yeast improved reproducibility of both males and females.

\section{Summary}

Performance of the hens and cocks of five generations on either the control diet or the diet containing $15 \%$ of one of four kinds of yeast grown on $n$-paraffin by four domestic manufacturers was combined and analysed statistically. The meat and eggs of the hens of 
the third generation fed either the control or yeast diet for longer than two years were analyzed chemically for nucleic acids, heavy metals, i.e. $\mathrm{Hg}, \mathrm{Pb}, \mathrm{Cd}$ and $\mathrm{As}$, and polycyclic aromatic compounds such as benzpyrene, which are suspected to be carcinogenic.

Followings were obtained as conclusion of the experiments reported in this and previous papers:

1. Yeast grown on $n$-paraffin is an excellent source of protein, energy and phosphorus for poultry, except sulphur amino acids and vitamin $B_{12}$, of which content in yeast is low for poultry feed, resembling the nutritive nature of soybean meal.

2. No evidence is obtained indicating that the yeast contains such a large quantity of toxic substance that the meat and eggs produced by the yeast feeding are injurious to human health. No data are obtained suggesting that the yeast feeding is unfavorable to produce the meat and eggs of good quality.

3. It is suggested that the yeast contains some vital factor or factors which keeps hens on the yeast healthy and productive.

\section{Literature}

1) Kosaka, K., H. Hoshin and M. Yoshida: Japan. Poultry Sci., 9, 159, 1972.

2) Yoshida, M., H. Ikumo and H. Hoshil: Ibid., 9, 231, 1972.

3) Yoshida, M., M. Tada, H. Bansho, M. Matsushima, K. Ogata, M. Iino and I. Umeda: Ibid., 9, 173, 1972.

4) Yoshida, M., M. Tada, H. Bansho, M. Matsushima, K. Koba, M. Iino and I. Umeda: Ibid., 10, $63,1973$.

5) Yoshida, M., M. Tada, H. Bansho, M. Matsushima, K. Koba, M. Iino and I.Umeda: Ibid., 11, 163, 1974.

6) Yoshida, M., M. Tada, H. Bansho, M. Matsushima, K. Koba, M. Ino and I. Umeda: Ibid., 11, $179,1974$.

7) Yoshida, M.: Ibid., 11,194,1974.

8) Yoshida, M., M. Tada, H. Bansho, M. Matsushima and I. Umeda: Ibid., 11, 217, 1974.

9) Yoshida, M.: Design of Experiments for Animal Husbandry, Yokendo, Tokyo, 1975.

10) Schmidt, G. and S. J. Thannhalser: J. Biol. Chem., 161, 83, 1945.

11) Kandatsu, M. and Y. Saito: Nippon Nogeikagaku Kaishi, 42, 479, 1968.

12) Tanabe. H.: Shokuhin Eisei Kenkyu 'J. Food Hygienic Research in Japanese) 23, 999, 1973.

13) Standard Methods of Analysis for Hygienic Chemists. - With Commentary Authorized by the Pharmaceutical So،iety of Japan: Kimbara Shuppan K. K. Tokyo, Japan, 1973.

14) Matsushita, H.: Japan Analyst, 19, 951, 1970.

15) J.A. O. A. C., 51, 449, 1968.

16) Tada, M., H. Furuichi, F. Seno, H. Baisho, K. Yamanaka, N. Inase and S. Yahata: Japan. Pou'try Sii., 10, 93, 1973.

17) Yoshida, M. and H. Hoshir: Ibid., 11, 225, 1974.

18) Yoshida, M.: Ibid., 8, 131, 1971.

19) Yoshida, M., H. Morimoto and R. Oda: Agr. Biol. Chem., 34, 1301, 1970.

20) Yoshida, M. and T. Horiuchi: Japan. Poultry Sci, 12, 96, 1975.

21) Research on Efficient Utilization of Protein Source and Development of Novel Protein Source.: Edited by Agricultural Research Council, Ministry of Agriculture and Forestry, in press. 


\title{
炭化水素酵母が飼料蛋白質給源として種鵎の繁殖能力におよぼす影響
}

\section{V. 累代飼養試験の総合的検討}

\author{
吉田 実 ${ }^{1)}$ - 多田昌男 ${ }^{21}$ - 番匠宏行 ${ }^{31}$ ・松島正洋 ${ }^{4}$ \\ 木庭研二 ${ }^{5)} \cdot$ 飯野雅夫 ${ }^{6)} \cdot$ 梅田 勲 $^{71}$ \\ 1）農林省畜産試験場 4）鳥取県中小家畜試験場 \\ 2）岡山県養鶏試験場 5）熊本県養䳕試験場 \\ 3）広島県立畜産試験場 6）埼玉県養䳕試験場 \\ 三 次支場 7) 岐阜県種鷄場
}

対照飼料もしくは炭化水素酵母を $15 \%$ 含导飼料を与 えた 5 世代の雄および雌鵴の成績を総今して解析すると ともに, 3 代鶏で 2 年以上対照もしくは醉母飼料を与兄 たものの肉と卵について, 核酸, 重金属すなわち水銀, 鉛, カドミウムおよびヒ素, ならびに発ガン性が考光ら れる多環芳香族化合物の含量堂測定した。醉母は国内 4 社の製品である。

本報およぴ前報の実験結果を総公して,つぎのような 結論がえられた。

1. 炭化水素醅母は, 養鵴用飼料の蛋白質, エネルギ
一およびリンの給源としてすぐれている。ただ，大豆粕 の栄養的特徵と似ていて, 含硫了ミノ酸とビタミン $\mathrm{B}_{12}$ が不足するので注意する必要がある。

2. 醉线を与えて生産した肉や卵を食べる人の健康を 損ならほどの多量の有害物質が，酵母に含まれている之 はいえない。また，醉母を与えて生産した肉や卵の品質 が劣るというデータはえられなかった。

3. 醅母には鶏の健康を維持し, 生産力を高める活性 因子が含まれていることが示唆された。

(家禽会誌，12，83９2，1975） 